\title{
The effects of prestorage incubation of quail breeder eggs on hatchability and subsequent growth performance of progeny
}

\author{
Metin PETEK*, Serdal DIKMEN
}

Department of Zootechnics, Faculty of Veterinary Medicine, University of Uludag, Bursa-16059, Turkey

(Received 16 March 2004; accepted 10 September 2004)

\begin{abstract}
A total of 1800 quail eggs were collected from two different flocks aged 20 and 37 wk. Prior to storage, half of the eggs were exposed to a prestorage incubation of $8 \mathrm{~h}$ (PRESI) and the other half were not (control). Eggs at $8 \mathrm{~h}$ PRESI were incubated at a standard dry-bulb temperature of $37.5^{\circ} \mathrm{C}$. After the PRESI treatment, all eggs were stored as the controls at $15^{\circ} \mathrm{C}$ and $65 \%$ relative humidity for 5 or $15 \mathrm{~d}$ and were turned twice a day. All eggs were weighed prior to and after storage, then incubated in a commercial setter and hatcher for $17 \mathrm{~d}$. After incubation, all unhatched eggs were opened to determine fertility, hatchability and stage of embryonic death. The PRESI treatment of $8 \mathrm{~h}$ significantly improved the hatchability of the total eggs (82.6\%) compared to the control $(79.7 \%)$. The hatchability of total eggs obtained from young breeders was significantly greater $(84.7 \%)$ compared to that of old breeders (77.6\%). No significant difference was observed for the hatchability due to the length of storage. Subsequent growth performance of progeny was not significantly influenced by the tested main effects, except for the storage treatment. The average body weight of $42 \mathrm{~d}$ old quails hatched from eggs stored for $5 \mathrm{~d}$ was $(191.3 \mathrm{~g})$ higher than after $15 \mathrm{~d}$ of storage $(174.4 \mathrm{~g})$. PRESI $(8 \mathrm{~h}$ ) reduced mortality and feed conversion ratio (FCR) of quails issued from young breeders and not that of quails issued from old breeders. It also improved the FCR of 42 d-old quails to a larger extent when the eggs were stored for $15 \mathrm{~d}$ compared to $5 \mathrm{~d}$ (interaction, $P<0.03$ ). It is concluded that $8 \mathrm{~h}$ PRESI does not have a detrimental effect on the hatchability of eggs and may even increase hatchability and subsequent performance of progeny issued from young breeders. Further research is needed to precisely determine the number of hours of PRESI required for maximum hatchability.
\end{abstract}

quail / incubation / egg storage / breeder age / reproduction / growth

Résumé - Les effets d'une pré-incubation sur l'éclosabilité des œufs de cailles reproductrices et la croissance des cailleteaux. Un total de 1800 œufs de caille ont été obtenus à partir de deux troupeaux âgés de 20 et 37 semaines. Avant le stockage, la moitié des œufs a subi une pré-incubation à $37,5^{\circ} \mathrm{C}$ (groupe PRESI) pendant 8 heures et l'autre moitié non (groupe témoin). Après la préincubation, les oufs du groupe PRESI comme ceux du groupe témoin ont été stockés à $15^{\circ} \mathrm{C}$ et $65 \%$ d'humidité relative pendant 5 ou $15 \mathrm{j}$ et ont été tournés deux fois par jour. Tous les œufs ont été pesés avant et après stockage, puis incubés pendant $17 \mathrm{j}$ dans un incubateur commercial. A la fin de cette période, tous les œufs non éclos ont été cassés afin de déterminer la fertilité, l'éclosabilité et

\footnotetext{
* Corresponding author: petek@uludag.edu.tr
} 
le stade de mortalité embryonnaire éventuelle. Le traitement PRESI $8 \mathrm{~h}$ a significativement amélioré l'éclosabilité des œufs (82,6\%) par rapport au groupe témoin (79,7\%). Le taux d'éclosion des œufs obtenus avec les jeunes reproducteurs a été supérieur $(84,7 \%)$ à celui obtenu avec les reproducteurs plus âgés $(77,6 \%)$. Aucune différence significative liée à la durée du stockage n'a pu être détectée. La croissance des jeunes n'a été significativement modifiée que par la durée du stockage. Le poids corporel moyen à $42 \mathrm{j}$ des cailleteaux issus des œufs stockés $5 \mathrm{j}$ a été de 191,3 g alors qu'il était seulement de $174,5 \mathrm{~g}$ après $15 \mathrm{j}$ de stockage. Le traitement PRESI a réduit la mortalité et l'indice de consommation (IC) des cailleteaux issus des jeunes reproducteurs, mais pas ceux des cailleteaux issus des reproducteurs plus âgés. Il a également amélioré l' IC des cailleteaux à $42 \mathrm{j}$, notamment celui des œufs stockés pendant $15 \mathrm{j}$ comparativement à ceux stockés pendant $5 \mathrm{j}(P<0,03)$. La pré-incubation (PRESI) pendant $8 \mathrm{~h}$ n'a pas eu d'effet négatif sur l'éclosabilité, elle peut même améliorer l'éclosabilité des œufs et les performances des cailleteaux issus de jeunes reproducteurs. Des études complémentaires restent à mettre en oeuvre pour mieux déterminer la durée optimale de préincubation requise pour obtenir un taux d'éclosabilité maximal.

cailles / incubation / stockage des œufs / âge / reproduction / croissance

\section{INTRODUCTION}

A number of methods have been investigated to improve the hatchability of eggs, especially when stored for more than seven days. These methods include various storage temperatures and humidity levels; enclosing eggs in plastic bags and injecting oxygen, carbon dioxide or nitrogen into the bags; and turning eggs during storage [12, 13]. Recently, it was reported that pre-heating of poultry eggs before storage resulted in more live chicks and a lower level of embryonic mortality compared to eggs that were not heated $[2,6,7,11]$. However, no previously conducted research has tested pre-incubation storage (PRESI) as a method for improving the hatchability of quail eggs, and its interactions with breeder age and length of storage period. The specific goal of this study was to determine if PRESI would improve the hatchability of quail eggs. The second objective was to determine the interactions of different breeder ages and length of storage of the eggs with the PRESI treatment on the hatchability and subsequent growth performance of progeny chicks.

\section{MATERIALS AND METHODS}

The experimental procedures conducted in this study were in accordance with the principles and guidelines set out by the
Committee of Veterinary Medicine. Freshly laid quail eggs were collected from two flocks aged 20 or $37 \mathrm{wk}$. At the time of collection, 900 eggs selected at random from each flock were weighed and randomly distributed into two groups of 450 eggs respectively exposed to an egg storage lasting 5 or 15 days. Eggs in each egg storage treatment group were randomly allocated to two groups of 225 eggs exposed to the PRESI treatment for 8 hours or not (control). Eggs for the 15-d storage group were collected $10 \mathrm{~d}$ prior to the eggs collected for the $5 \mathrm{~d}$ storage group, so that all the eggs from all groups could be set in the incubator at the same time. There was a total of 8 treatments according to a factorial design $(2$ breeder ages $\times 2$ storage periods $\times 2$ PRESI treatments) with 5 repetitions of 45 eggs per replicate.

\subsection{Management}

Eggs at $8 \mathrm{~h}$ PRESI were incubated at a standard dry-bulb incubation temperature of $37.5^{\circ} \mathrm{C}$. After the PRESI treatment was completed, all eggs were stored at an average temperature of $15^{\circ} \mathrm{C}$ and relative humidity of $65 \%$ for 5 or $15 \mathrm{~d}$ and were turned twice a day. All eggs were weighed after storage, and the eggs from each group were incubated in a commercial setter and hatcher for $17 \mathrm{~d}$. The setter was operated at $37.5 \pm$ $0.5{ }^{\circ} \mathrm{C}$ dry bulb temperature and $29.0 \pm$ $0.5^{\circ} \mathrm{C}$ wet bulb temperature. The hatcher 
was operated at $37.0 \pm 0.5^{\circ} \mathrm{C}$ dry bulb temperature and $31.0 \pm 0.5^{\circ} \mathrm{C}$ wet bulb temperature. The eggs in the setter were turned 15 times per day. Trays representing all treatment groups were distributed in all positions in the setter and hatcher $(45 \times 8=$ 360 eggs per tray and 5 trays in the incubator). Newly hatched chicks in all groups were reared under the same growing conditions in brooding cages (colony type) in an open-sided house with mechanical ventilation. Chicks belonging to the same group were randomly distributed into five replicates at hatching. All chicks were brooded and reared at $28^{\circ} \mathrm{C}$ for the 1 st wk, $27^{\circ} \mathrm{C}$ for the $2 \mathrm{nd} \mathrm{wk}, 24^{\circ} \mathrm{C}$ for the $3 \mathrm{rd} \mathrm{wk}$, and 18 $21^{\circ} \mathrm{C}$ from the 28 th day until 42 days of age. Standard production practices and standard quail feed produced in the centre were used during the treatment. The diets were formulated using the NATIONAL RESEARCH COUNCIL [14] guidelines (220 $\mathrm{g} \cdot \mathrm{kg}^{-1}$ protein and $3185 \mathrm{kcal} \cdot \mathrm{kg}^{-1}$ metabolisable energy). The chemical composition of the diets was controlled using the international procedures of AOAC and Hartel [3, 9]. All birds had ad libitum access to feed and water. Twenty-four $h$ lighting were used throughout the growth period. Data for the growth performance were collected from hatching to $42 \mathrm{~d}$ of age.

\subsection{Data and statistical analysis}

After the eggs were separated into the treatment groups, the fresh egg weights were compared among the treatment groups. Three days after removing the chicks from the hatcher, all unhatched eggs were opened to determine fertility. If the eggs were fertile, the period of embryonic development was determined according to Hermes [10]. The hatchability of fertile or total eggs was calculated as the number of chicks hatched per fertile or total eggs $[1,20]$. The fertility results are reported as apparent fertility. Individual body weights of quail were measured at hatching and at $42 \mathrm{~d}$ of age, and cumulative feed conversion ratio $(\mathrm{FCR}=$ grams of feed intake per grams of body weight gain) was calculated from 0 to $42 \mathrm{~d}$ of age. FCR of progeny in all groups was corrected for mortality by calculating the average individual feed intake for each week. Mortality was recorded on a per group basis as it occurred.

The hatchability and growth data were analysed by three way ANOVA with two levels of PRESI ( 0 and $8 \mathrm{~h})$, two levels of breeder age (20 and $37 \mathrm{wk}$ ) and two levels of egg storage ( 5 and $15 \mathrm{~d}$ ). When an interaction was significant, the Duncan multiple mean comparison test was used to compare treatment means. All data in percentages were transformed using arc sine square root transformations prior to analysis [17]. The statistical analyses for apparent fertility, hatchability of total and fertile egg, body weight, feed conversion and mortality were calculated on the basis of the replicates (5 per treatment). All tests were performed using SPSS $^{\circledR}$ computer software 10.00 [18]. The PRESI treatment, breeder age, and length of storage were the main effects.

\section{RESULTS}

The main effects of PRESI, breeder age, and egg storage on egg weight loss, apparent fertility, hatchability of total and fertile eggs, and embryonic mortality are presented in Table I. Fresh egg weights were not significantly different among treatments. The triple interactions between the three main effects were never significant. Eggs lost significantly more weight during storage after PRESI $8 \mathrm{~h}$ and when the storage duration was longer $(15 \mathrm{~d})$ than for control eggs and short storage $(5 \mathrm{~d})$. There were significant PRESI $\times$ breeder age interactions for the hatchability of total and fertile eggs. Hatchability was improved more by PRESI $(+4.4 \%)$ in eggs issued from young breeders compared to older ones $(+1.4 \%)$. Breeder age $\times$ egg storage interaction was also found significant for the hatchability of total eggs. Hatchability was only significantly reduced by a longer egg storage duration when the eggs were produced by older breeders. Hatchability of total and fertile eggs were found 
significant due to the main effect of the PRESI treatment. Breeder age and egg storage did not significantly affect the hatchability of fertile eggs. The differences for the apparent fertility among the main groups were not significant. The total mortality rates of embryos did not significantly differ according to the duration of storage or to the age of breeders. However, PRESI did reduce embryo mortality significantly by a third. This effect was spread for all embryonic periods tested (Tab. I).

The subsequent growth performances of progeny in the main groups are presented in Table II. The body weight at hatching in the main groups was found to be similar. A longer storage of the eggs (15 d) significantly reduced the BW of quails at $42 \mathrm{~d}$ of age $(172.4 \mathrm{~g})$ compared to a $5 \mathrm{~d}$ storage period $(191.3 \mathrm{~g})$ and significantly increased their FCR by $10 \%$ (Tab. II). There was a significant PRESI $\times$ breeder age interaction for FCR and mortality of progeny and PRESI $\times$ egg storage interaction for FCR of progeny. PRESI reduced by half the mortality of chicks issued from young breeders although it did not change the mortality rate of chicks issued from old breeders (Tab. III). In parallel to this effect on mortality, the FCR was only reduced by PRESI in chicks issued from young breeders. A longer egg storage $(15 \mathrm{~d})$ degraded the FCR of progeny to a smaller extent when PRESI was applied (interaction $P<0.03$ ).

\section{DISCUSSION}

In the present study, egg weight losses during the storage were significantly increased by main effects of PRESI treatment and the length of egg storage. This result was expected, since exposure to PRESI and a long time of storage would increase water evaporation from the eggs. The PRESI treatments or the interactions with the duration of the storage period or breeder age did not significantly affect apparent fertility. However, previous research [15] has demonstrated that a long period of egg storage prior to incubation may decrease apparent fertility. The fact that the collection of the eggs for the 5 and $15 \mathrm{~d}$ storage groups was separated by $10 \mathrm{~d}$ in the present experiment might have interfered with the fertility results that are on average not significantly $(4.6 \%)$ lower after $15 \mathrm{~d}$ of storage compared to $5 \mathrm{~d}$.

In this study, $8 \mathrm{~h}$ PRESI of the eggs prior to storage significantly improved the hatchability of total and fertile eggs issued from young breeders (Tab. III). This result was expected in accordance with the previous reports in quail and other species related to egg storage and PRESI [2, 5-7, 11, 15, 22]. Some embryos of eggs stored for long periods cannot start developing immediately after normal incubation temperatures are provided. Another possibility is that the development of embryos from eggs stored for a long period proceeds at a slower rate through the first period of incubation. However, it remains unclear in the present study why the effect of PRESI on hatchability was clearer in young breeders compared to older ones and why this positive effect on hatchability seems to have been carried over to progeny livability and FCR. If the positive effect of PRESI was only linked to the duration of storage as suggested by other research reports, there should be a significant interaction between PRESI and the duration of storage of the eggs. This interaction was only observed for the FCR of the progeny. Our experiment suggests that young breeders may benefit from a PRESI treatment even when eggs are stored for only $5 \mathrm{~d}$ prior to incubation.

As reported in previous studies on broiler breeders [4, 19], the age of the quail breeder significantly reduced the overall hatchability of the total eggs. The eggs obtained from young breeders produced more chicks. In this study, total embryonic mortality of eggs in $8 \mathrm{~h}$ PRESI treatment was significantly reduced compared to the non heated group. Most probably, embryos in PRESI are being pushed to the optimal stage of development to safely store eggs $[6,8]$. However, 
Table I. The effects of PRESI, egg storage and breeder age on egg weight loss, embryonic mortality, fertility, and hatchability of total and fertile eggs.

\begin{tabular}{|c|c|c|c|c|c|c|c|c|c|}
\hline \multirow[t]{2}{*}{ Main treatment effects } & \multirow{2}{*}{$\begin{array}{l}\text { Fresh egg } \\
\text { weight } \\
\quad(\mathrm{g})\end{array}$} & \multirow{2}{*}{$\begin{array}{l}\text { Egg weight loss } \\
\text { during storage } \\
(\%)\end{array}$} & \multirow{2}{*}{$\begin{array}{l}\text { Apparent } \\
\text { fertility } \\
(\%)\end{array}$} & \multirow{2}{*}{\multicolumn{2}{|c|}{\begin{tabular}{cc}
\multicolumn{2}{c}{ Hatchability of } \\
Total eggs & Fertile eggs \\
$(\%)$ & $(\%)$
\end{tabular}}} & \multicolumn{4}{|c|}{$\begin{array}{c}\text { Embryonic mortality during incubation } \\
(\%)\end{array}$} \\
\hline & & & & & & $1-7 \mathrm{~d}$ & $7-14 \mathrm{~d}$ & $14-17 \mathrm{~d}$ & Total \\
\hline \multicolumn{10}{|l|}{ PRESI (h) } \\
\hline 0 & 12.33 & 0.32 & 90.8 & 79.7 & 85.3 & 3.80 & 3.08 & 4.08 & 10.96 \\
\hline 8 & 12.35 & 0.81 & 91.8 & 82.6 & 90.4 & 2.59 & 1.50 & 3.63 & 7.72 \\
\hline \multicolumn{10}{|l|}{ Breeder age } \\
\hline Young & 12.48 & 0.64 & 93.7 & 84.7 & 88.3 & 3.75 & 2.86 & 3.66 & 10.27 \\
\hline Old & 12.23 & 0.74 & 88.9 & 77.6 & 87.4 & 2.64 & 1.72 & 4.05 & 8.47 \\
\hline \multicolumn{10}{|l|}{ Egg storage $(d)$} \\
\hline 5 & 12.36 & 0.49 & 93.6 & 82.1 & 88.1 & 3.33 & 1.38 & 5.22 & 9.93 \\
\hline 15 & 12.33 & 0.73 & 89.0 & 80.2 & 87.6 & 3.06 & 3.19 & 2.50 & 8.75 \\
\hline \multicolumn{10}{|l|}{ ANOVA } \\
\hline PRESI & ns & 0.017 & ns & 0.001 & 0.001 & ns & $\mathrm{ns}$ & ns & 0.01 \\
\hline Breeder age & ns & ns & ns & 0.001 & $\mathrm{~ns}$ & $\mathrm{~ns}$ & ns & $\mathrm{ns}$ & ns \\
\hline Egg storage & $\mathrm{ns}$ & 0.001 & ns & ns & ns & ns & ns & 0.01 & ns \\
\hline PRESI $\times$ Breeder age & ns & ns & ns & 0.005 & 0.019 & ns & $\mathrm{ns}$ & ns & $\mathrm{ns}$ \\
\hline PRESI $\times$ Egg storage & ns & ns & ns & ns & ns & ns & ns & ns & ns \\
\hline Breeder age $\times$ Egg storage & $\mathrm{ns}$ & ns & ns & 0.001 & ns & ns & ns & ns & ns \\
\hline PRESI $\times$ breeder age $\times$ Egg storage & ns & ns & ns & ns & ns & ns & ns & ns & ns \\
\hline SEM & 0.46 & 0.13 & 1.20 & 1.02 & 1.30 & 0.32 & 0.45 & 0.69 & 0.56 \\
\hline
\end{tabular}

PRESI: prestorage incubation; ns: not significant. 
Table II. Main effects of PRESI, breeder age, and length of storage period on growth performance.

\begin{tabular}{|c|c|c|c|c|c|}
\hline \multirow[t]{2}{*}{ Main treatment effects } & \multirow[t]{2}{*}{$\mathrm{n}$} & \multicolumn{2}{|c|}{ Body weight (g) } & \multirow[t]{2}{*}{ FCR } & \multirow[t]{2}{*}{ Mortality (\%) } \\
\hline & & At hatch & At $42 \mathrm{~d}$ of age & & \\
\hline \multicolumn{6}{|l|}{ PRESI (h) } \\
\hline 0 & 717 & 8.6 & 185.3 & 4.17 & 8.04 \\
\hline 8 & 743 & 8.4 & 180.5 & 3.91 & 7.00 \\
\hline \multicolumn{6}{|l|}{ Breeder age } \\
\hline Young & 762 & 8.7 & 182.0 & 3.67 & 6.74 \\
\hline Old & 698 & 8.3 & 183.9 & 4.31 & 8.29 \\
\hline \multicolumn{6}{|l|}{ Egg storage $(\mathrm{d})$} \\
\hline 5 & 739 & 8.5 & 191.3 & 3.75 & 7.46 \\
\hline 15 & 721 & 8.5 & 174.4 & 4.32 & 7.58 \\
\hline \multicolumn{6}{|l|}{ ANOVA } \\
\hline PRESI & & ns & ns & ns & $\mathrm{ns}$ \\
\hline Breeder age & & ns & ns & 0.001 & 0.001 \\
\hline Egg storage & & $\mathrm{ns}$ & 0.002 & 0.001 & $\mathrm{~ns}$ \\
\hline PRESI $\times$ Breeder age & & ns & ns & 0.001 & 0.001 \\
\hline PRESI $\times$ Egg storage & & ns & ns & 0.022 & ns \\
\hline Breeder age $\times$ Egg storage & & ns & ns & ns & ns \\
\hline PRESI $\times$ Breeder age $\times$ Egg storage & & ns & ns & ns & ns \\
\hline SEM & & 0.1 & 4.3 & 0.17 & 0.41 \\
\hline
\end{tabular}

n: number of chicks at hatch; FCR: feed conversion ratio; PRESI: prestorage incubation; ns: not significant.

Table III. Mean of significant interactions for different traits.

\begin{tabular}{lcccc}
\hline & \multicolumn{4}{c}{ PRESI $\times$ Breeder age interactions } \\
\cline { 2 - 5 } Traits & $0 \mathrm{~h}$-Young & 0 h-Old & $8 \mathrm{~h}$-Young & $8 \mathrm{~h}$-Old \\
\hline Hatchability of total eggs & $82.5^{\mathrm{b}}$ & $76.9^{\mathrm{c}}$ & $86.9^{\mathrm{a}}$ & $78.3^{\mathrm{c}}$ \\
Hatchability of fertile eggs & $85.1^{\mathrm{c}}$ & $85.4^{\mathrm{c}}$ & $91.6^{\mathrm{a}}$ & $89.3^{\mathrm{b}}$ \\
FCR & $3.82^{\mathrm{b}}$ & $4.28^{\mathrm{a}}$ & $3.31^{\mathrm{c}}$ & $4.29^{\mathrm{a}}$ \\
Mortality & $8.7^{\mathrm{a}}$ & $7.4^{\mathrm{a}}$ & $4.8^{\mathrm{b}}$ & $9.2^{\mathrm{a}}$ \\
\hline & \multicolumn{5}{c}{ Breeder age $\times$ Egg storage interaction } \\
\cline { 2 - 5 } & Young-5 d & Old-5 d & Young-15 d & Old-15 d \\
\hline Hatchability of total eggs & $84.0^{\mathrm{a}}$ & $80.2^{\mathrm{b}}$ & $85.4^{\mathrm{a}}$ & $75.0^{\mathrm{c}}$ \\
\hline & \multicolumn{5}{c}{ PRESI $\times$ Egg storage interaction } \\
\cline { 2 - 5 } & $0 \mathrm{~h}-5 \mathrm{~d}$ & $0 \mathrm{~h}-15 \mathrm{~d}$ & $8 \mathrm{~h}-5 \mathrm{~d}$ & $8 \mathrm{~h}-15 \mathrm{~d}$ \\
\hline FCR & $3.71^{\mathrm{a} b}$ & $4.39^{\mathrm{c}}$ & $3.58^{\mathrm{a}}$ & $4.02^{\mathrm{b} \mathrm{c}}$ \\
\hline
\end{tabular}

PRESI: prestorage incubation; FCR: feed conversion ratio.

a, b, c Within rows, values with different superscript differ significantly at $P<0.05$. 
embryonic mortality rates in each stage of incubation examined in this study were not significantly affected by the main and their interactive effects, except for the main effect of storage period on mortality from 14 to $17 \mathrm{~d}$ of incubation (Tab. I). A comparison of the main effects between two PRESI treatments, two storage periods and two breeder ages showed that 8 h PRESI treatment had a significant beneficial effect on hatchability and embryonic mortality; however, the embryos of eggs stored $15 \mathrm{~d}$ resulted in noticeably lower hatchabilities and mortalities from 14 to $17 \mathrm{~d}$ of incubation and the eggs obtained from young breeders significantly produced more chicks.

In this study, neither the PRESI nor the breeder age significantly influenced the subsequent body weight of the progeny. The result for the progeny body weight was not similar with the findings of Shanawany [16], Tserveni-Gousi [21] and Yannakopoulos et al. [23], who reported that the weight gain of chicks can be affected by parental age. Egg storage for $15 \mathrm{~d}$ significantly depressed the body weight of quail probably due to an increase of second grade chicks at hatch after prolonged storage time.

The feed conversion ratios of progeny hatched from $15 \mathrm{~d}$ stored eggs and old breeder groups were significantly greater than those of progeny hatched from $5 \mathrm{~d}$ stored eggs and young breeders, respectively. However, the present results do not corroborate previous observations in which body weight and the FCR of progeny were not affected by the length of egg storage [15]. The mortality rate of progeny was not significantly affected due to the main effects in the present study, except for the main effect of breeder age. The survival rate of quail hatched from old breeders was found to be lower. PRESI treatment improved FCR and reduced mortality only for young breeders. Although PRESI treatment improved FCR in both storage treatments, its effect on $15 \mathrm{~d}$ stored eggs was clearer. The effects and interaction between PRESI and breeder age on mortality of progeny in the present exper- iment might have interfered with some results. The main causes of mortality in each treatment group are probably placing the birds in colony type cages. Pecking and cannibalism are often a bigger problem in colony type cages since they are not able to escape and hide from the more aggressive birds.

The results of the present study show that $8 \mathrm{~h}$ PRESI have a positive effect on the hatchability of quail eggs and subsequent growth performance of progeny issued from young breeders. Hence, PRESI of eggs could be used by the industry as a method to improve the hatchability of hatching eggs. Further research is needed to determine the optimum length of PRESI time and storage durations to reach maximum hatchability. Meanwhile, it should be kept in mind that the economic cost of PRESI must be evaluated in comparison with its beneficial effects.

\section{ACKNOWLEDGEMENTS}

The authors thank Dr. Recep Cibik, and Dr. Hakan Sagirkaya for their editorial assistance in the preparation of the manuscript.

\section{REFERENCES}

[1] Akcapinar H., Ozbeyaz C., Hayvan Yetistiriciligi Temel Bilgileri (in Turkish), Kariyer Matb. Ltd. Şti publishing house, Ankara, Tukey, 1999, p. 83.

[2] Anonymous, Preheating of ostrich eggs (Abstract), Int. Hatch. Pract. 14 (2000) 32.

[3] AOAC, Official Methods of Analyses, Association of Agricultural Chemists, Virginia, 1990

[4] Elibol O., Peak S.D., Brake J., Effect of flock age, length of egg storage, and frequency of turning during storage on hatchability of broiler hatching eggs, Poult. Sci. 81 (2002) 945-950.

[5] Fasenko G., How are embryo and poultry? Viability, hatchability, and growth affected by storing turkey eggs for long periods, Alberta Poult. Res. Centre News 6 (1997) 1.

[6] Fasenko G.M., Christensen V.L., Wineland M.J., Petitte J.N., Examining the effects of prestorage incubation of turkey breeder eggs 
on embryonic development and hatchability of stored for four or fourteen days, Poult. Sci. 80 (2001) 132-138.

[7] Fasenko G.M., Robinson F.E., Whelan A.I., Kremeniuk K.M., Walker J.A., Prestorage incubation of long-term stored broiler eggs; 1 . Effects on hatchability, Poult. Sci. 80 (2001) 1406-1411.

[8] Gupta S.K., Bakst M.R., Turkey embryo staging from cleavage through hypoblast formation, J. Morphol. 217 (1993) 313-325.

[9] Hartel H., Between N-correlated metabolizable energy and nutrient content of feeds for chickens, Arch. Geflugelkd. 41 (1977) 152182.

[10] Hermes J.C., Quail Embryo Series, Classroom program through Poultry Extension, at Oregon State University, [Online], Available: www.oregonstate.edu/dept/animal-sciences/ poultext/slides 1.htm [September 2004].

[11] Laurens S., Heating of hatching eggs before storage improves hatchability, World Poult. 18 (2002) 24-25.

[12] Mayes F.J., Takeballi M.A., Storage of the eggs of the fowl (Gallus Domesticus) before incubation. A Review, World's Poult. Sci. J. 40 (1984) 131-140.

[13] Meijerhof R., Pre-incubation holding of hatching eggs, World's Poult. Sci. J. 48 (1992) 57-68.

[14] National Research Council, Nutrient Requirements of Poultry, 9th revised ed., National Academy Press, Washington, DC, 1994.
[15] Petek M., Baspinar H., Ogan M., Effects of egg weight and length of storage period on hatchability and subsequent growth performance of quail, S. Afr. J. Anim. Sci. 4 (2003) 242-247.

[16] Shanawany M., Hatching weight in relation to egg weight in domestic birds, World's Poult. Sci. J. 43 (1987) 107-115.

[17] Snedecor G.W., Cochran W.G., Statistical Methods, 8th ed., Iowa State University Press, Ames, IA, USA, 1989.

[18] SPSS ${ }^{\circledR} 10.00$ Computer Software, SPSS Inc., Headquarters, 233 s.Wacker Drive, Chicago, Illinois 60606, USA, 1999.

[19] Suarez M.E., Wilson H.R., Mather F.B., Wilcox C.J., McPherson B.N., Effects of strain and age of broiler breeder female on incubation time and chick weight, Poult. Sci. 76 (1997) 1029-1036.

[20] Taylor G., Egg Handling Techniques, 2nd ed., Medina, Ohio, USA, 1998, pp. 4-10.

[21] Tserveni-Gousi A.S., Relationship between parental age, egg weight and hatching weight of Japanese quail, Br. Poult. Sci. 28 (1987) 749-752.

[22] Uddin M.S., Paul D.C., Huque Q.M.E., Effect of egg weight and pre-incubation holding periods on hatchability of Japanese quail eggs in different seasons, Asian Austral. J. Anim. 7 (1994) 499-503.

[23] Yannakopoulos A.L., Tserveni-Gousi A.S., Effect of breeder quail age and egg weight on chick weight, Poult. Sci. 66 (1987) 15581560 . 